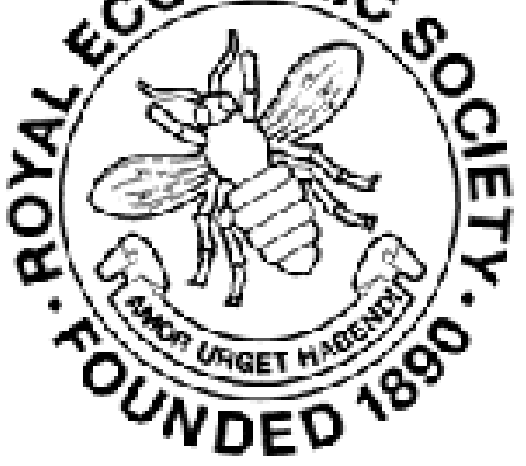

\title{
WILEY
}

The Factory and Workshops Acts Amendment Bill

Author(s): Mona Wilson

Source: The Economic Journal, Vol. 11, No. 42 (Jun., 1901), pp. 268-271

Published by: Wiley on behalf of the Royal Economic Society

Stable URL: http://www.jstor.org/stable/2957173

Accessed: 27-06-2016 04:10 UTC

Your use of the JSTOR archive indicates your acceptance of the Terms \& Conditions of Use, available at

http://about.jstor.org/terms

JSTOR is a not-for-profit service that helps scholars, researchers, and students discover, use, and build upon a wide range of content in a trusted digital archive. We use information technology and tools to increase productivity and facilitate new forms of scholarship. For more information about JSTOR, please contact support@jstor.org.

Royal Economic Society, Wiley are collaborating with JSTOR to digitize, preserve and extend access to The Economic Journal 
tax which will now be shifted on to the foreigner depends, at least so far as exports to the north of Europe are concerned, largely on the question how far our coal is needed for purposes for which ordinary coal is inadequate. Fawcett in 1881, as in 1879, is arguing against the use of the duty as a retaliatory measure against France. But in 1881, while softening the purely economic side of his argument, he lays more stress on international comity, and urges that "instead of being induced to make concessions to England, hostility on our part would, there is every reason to expect, kindle increased hostility on the part of France, and a war of tariffs involving an incalculable loss to both countries would be commenced." With this, of course, I agree.

The technical difficulties connected with the tax have proved to be even greater than I supposed when I wrote to you last; but I share the common opinion that they are less than they are represented to be by the mining interests. I heartily sympathise with those miners who were opposed to the war, and who now fear they may have to pay more than their share of its expenses; but I venture to express an earnest hope that they will not be lured into a general suspension of work. Their power over England's prosperity is one of the most striking facts of the time; its full significance being, perhaps, not even yet generally understood. But much of that power is a result of the marvellous improvement in the character of the average miner during the last 50 years; and it would be a shortsighted policy to put a stain on their own good fame.

Yours faithfully,

\section{ALFRED MARSHALL}

May 7.

\section{The Factory and Workshops Acts Amendment Bill.}

IN 1900 the Government introduced a Factory and Workshops Acts Amendment Bill which was afterwards withdrawn on account of the opposition of Trade Unionists to various clauses. A consolidating Bill has been introduced this session, together with a new Amendment Bill. Legislation by order of the Secretary of State figured largely in the Bill of 1900. This was strongly opposed by Trade Unionists as placing too much power in the hinds of individual Home Secretaries, and also on account of the difficulty of enforcing regulations so made. The effect of this opposition can be traced in the new Bill, although the Secretary of State still has power in several instances to make provisions by order, notably those relating to the periods of employment and meal hours in laundries and Irish creameries.

The opening clauses deal with the establishment of special rules in dangerous trades. The Bill of 1900 nominally abolished the present system of arbitration on special rules, in cases when the 
proposals of the Home Office are objected to by the manufacturers and no agreement is arrived at. But reference to a person appointed by the Secretary of State, who must be neither a Factory Inspector nor a person affected, was substituted for arbitration. The Secretary of State was obliged to accept the recommendations of the referee, or withdraw the draft regulations without prejudice to his power of proposing a fresh set.

The new Bill goes a step further in the case of objection ${ }^{1}$ by or on behalf of persons affected, and unless the rules are amended by the Secretary of State and a fresh draft is issued, or unless such objection is withdrawn or appears to him to be frivolous, he must direct an inguiry to be made, and appoint a competent person. It is not binding on him to accept the recommendation of the person appointed, but the result of such inquiries would, in most cases, doubtless be some modification of the original proposal. The rules would be originally drafted after an inquiry conducted by the experts employed by the Department, and the objections raised could be considered by the Secretary of State, who could cause a fresh inquiry to be made by these experts. A third inquiry, by a person specially appointed, would presumably, therefore, be an inquiry of the same type as the present arbitrations, conducted by a person with no special knowledge of the industry, who is required to hear the case for the Home Office, for the manufacturers, and, should they make application, for the work-people. The rules, as finally drawn up, must be before both Houses of Parliament for six weeks before coming into force.

The provision for the exemption from special rules of any specified class of factories or workshops, either absolutely or subject to conditions, tends to weaken the force of the preceding clauses.

The clauses of the Bill which relate to outwork exhibit a marked tendency towards the transference of power from the Factory Department to the Local Authority. The Secretary of State has power, as at present, to require by order that occupiers and contractors in any trade shall keep lists of outworkers. These lists have, under the existing law, to be sent twice a year to the District Inspector, and must be open to inspection by any Factory Inspector and by any officer of a sanitary authority. The new Bill reverses the position-lists of outworkers must be supplied twice a year to the Local Authority, and must be shown to a Factory Inspector on application. The reason for depriving the District Inspector of these lists is not obvious. The Truck Acts are at present administered by the Factory Inspectors, and Clause 32 gives the Secretary of State power to extend the application of the Particulars Clause, which is also administered by the Factory Department, to any class of outworkers of whom lists are required to be kept. Clause 10 gives power to the Local Authority to make an order prohibiting the

1 Both Bills allow objections to be made by or on behalf of persons affected, i.e., employers and employed. Under the existing law objection by the occupier is alone provided for, but the workpeople may be represented at the arbitration 
giving out, making, cleaning, or repairing of wearing apparel to a house where any person is ill from a disease which is required to be notified under the Infectious Disease (Notification) Acts. No supervisory power is given to the Factory Department as in the case of the administration of the Public Health Acts. Abstracts of the provisions of the Factory Acts relating to domestic factories and workshops are to be issued by the Local Authority. Further, the Medical Officer of Health to each Local Authority, must report specifically on the administration of the Factory Acts, sending a copy of such report to the Secretary of State.

The provisions of the Factory Acts relating to the period of employment and meal hours for women, young persons, and children, are to be modified by order of the Secretary of State, "so as to adapt them to the special circumstances of laundries." The present weekly limits of employment, 30 hours for children and 60 hours for women and young persons, are not to be exceeded. This leaves overtime for women, arrangements as to mealtimes, and the daily maximum periods of employment, which are regulated by the existing law, entirely in the hands of the Home Secretary. It is surprising to find that laundries are again placed on a different footing from factories and workshops as regards periods of employment and mealtimes, in view of the opinions expressed by H. M. Inspectors of Factories. ${ }^{1}$ Hotel laundries, and laundries in connection with prisons, reformatories, \&c., will be included, but laundries attached to religious institutions are to be supervised by a visitor appointed by the Chief Inspector and nominated by the management. This exceptional treatment seems unnecessary, since the inspection of such places could be made a part of the duties of the Women Factory Inspectors. Laundries ordinarily employing members of the same family dwelling there, or not more than two other persons, are still to be excluded from the provisions of the Acts.

The exemption of certain processes of fish-curing, and of fruitpreserving during the summer months, have been repealed, but the provisions of the Acts respecting periods of employment and mealtimes are not to apply to these processes. As regards fish-curing, the definition of the processes so excepted covers a rather larger area than the definition of those now exempted.

The Secretary of State has power to vary the beginning and end of the daily period of employment and of mealtimes in Irish creameries, and to permit a maximum of three hours' work on Sundays and holidays.

One of the most extraordinary clauses in the Bill is that relating to the reporting of accidents. It provides that accidents causing loss of life to a person employed in a factory or workshop shall be reported by the occupier: other accidents shall be reported, whether causing injury or not, if they belong to a class of accidents specified by order of the Secretary of State. Under the existing law all accidents

${ }_{1} C f$. Annual Reports of H. M. Chief Inspectors of Factories, 1896, p. 68; 1897, p. $107 ; 1898$, p. 178 . 
causing injury to a person such as to disable him from carrying on his usual work for five hours on any of the three days following the accident must be reported. Any relaxation of the reporting of accidents and of the inquiries to which reporting gives rise must necessarily be followed by an increase in the number of accidents. It will be remembered that in addition to the specified cases, in which fencing is always required, all dangerous machinery must be fenced, and unless the contrary is proved the machinery is presumed to be dangerous if so notified by an inspector. In practice it may often happen that such a notification is not given until the occurrence of some accident by means of which the attention of an inspector has been directed to the machinery in question. If, therefore, fewer accidents are reported the result will be that fewer machines will be notified as dangerous, less fencing will be required, and more accidents will occur.

Among the clauses of minor importance is Clause 32, which gives statutory sanction to the power lately assumed by the Government to extend the present exemption which can be granted in times of national emergency to factories and workshops belonging to the Crown, so as to cover factories and workshops engaged on Government contracts. Clause 40, which provides that a person engaged in the same trade or offence as a person charged with an offence under the Factory and Workshops Acts, shall not act as a Justice of the Peace in hearing and determining the case has been shown in practice to be a much needed amendment.

No large conference of Trade Unionists such as that summoned in 1900 by the London Trade Council and the Women's Trade Union League has yet been held to consider the Bill, but a short memorandum calling attention to the more important clauses affecting women has been drawn up and issued by the Women's Trade Union League. This memorandum has also been adopted by the London Trade Council for distribution to branches.

Mona WiLson

\section{Trusts and Trade Combinations in Europe. (Vol. XXI., Part III. Special Consular Reports of the U.S.)}

THIs volume, which has lately been issued by the U. S. Bureau of Foreign Commerce, contains a series of special reports prepared by the U. S. Consuls in Europe on the subject of trusts and trade combinations. With the exception of Russia, every European country of any importance has been included in the field of inquiry. In examining the information thus collected, the first point that will strike the economic student is the rapidity with which this particular form of trade organisation is developing, a rapidity which seems likely to increase rather than diminish; while perhaps, a second point almost equally noticeable, is the moderation which has, as a general rule, 